\title{
TEMPERATURE AND SOAKING TIME CAUSE COLOR CHANGES OF FLEXIBLE DENTURE
}

\author{
Tri Purnami Dewi R, Dewi Farida Nurlitasari, I G A Pt Asri Septyanti \\ Faculty of Dentistry, Mahasaraswati Denpasar University \\ email: dewi_tripd@gmail.com
}

\begin{abstract}
Flexible denture is a removable partial denture made of flexible material and can adapt well to the oral tissues. Color stability is one of the basic properties of denture that is needed in achieving good aesthetics. Intrinsic and extrinsic factors can affect the basic denture's color changes. Extrinsic factors can be stain due to the absorption of pigments of dyes from exogenous sources such as denture cleansing solutions, food and beverages, length of use of materials either due to physical or chemical conditions, such as temperature changes. Intrinsic factors include chemical changes in the material itself, among others, due to the imperfect polymerization process, material pollution in the process of making the material or its processing, due to the chemical reaction within the material itself and various processing techniques resulting in the occurrence of porosity on the surface of the material to facilitate the accumulation of dirt. This study aims to observe the color change of the flexible denture base made of nylontermoplastic. The sample of this study used 30 flexible denture base plates measuring $10 \mathrm{~mm} \times 10 \mathrm{~mm} \times 2 \mathrm{~mm}$, soaked at different temperatures of $40^{\circ} \mathrm{C}, 50^{\circ} \mathrm{C}$ and $60^{\circ} \mathrm{C}$ for 1 minute, 3 minutes and 5 minutes in each group. The media used is waterbath as a temperature control and then processed using Adobe Photoshop with CIELab method. The results showed significant color changes in the $37^{\circ} \mathrm{C}$ temperature control group with temperatures of $40^{\circ} \mathrm{C}, 50^{\circ} \mathrm{C}$ and $60^{\circ} \mathrm{C}$ (p <0.05). Medium between $40^{\circ} \mathrm{C}, 50^{\circ} \mathrm{C}$ and $60^{\circ} \mathrm{C}$ has no significant difference $(\mathrm{p}>0,05)$. The conclusion is that the higher of the temperature and the duration of soaking time have a significant effect on the color change of flexible denture.
\end{abstract}

Keywords: temperature, soaking time, discoloration, flexible denture base

\section{PENDAHULUAN}

Kehilangan gigi sering ditemukan di masyarakat akibat kecelakaan, penyakit atau proses penuaan secara alami, sehingga menyebabkan perubahan anatomis, fisiologis maupun fungsional rongga mulut. Pemakaian gigitiruan dapat membantu memulihkan fungsi fonetik atau bicara, fungsi pengunyahan, fungsi estetik atau kecantikan, dan pemeliharaan jaringan mulut yang masih ada. Gigitiruan harus dibuat mirip dengan gigi asli yang masih ada sehingga tidak terlihat perubahan yang nyata pada penampilan wajah pasien.

Wurangian (2010) menyebutkan bahwa gigitiruan sebagian lepasan dapat dibedakan menurut bahan basis gigitiruannya yaitu gigitiruan kerangka logam dan gigitiruan akrilik. ${ }^{1}$ Penggunaan gigitiruan kerangka logam sering dikeluhkan oleh pasien karena kontruksi cengkeramnya yang tidak estetik dan kaku yang menyebabkan iritasi jaringan, memiliki insiden patah yang lebih tinggi dan memiliki dukungan logam dan clasps yang buruk. Resin akrilik dikenal dengan nama polimethylmetacrylate atau PMMA, juga memiliki kekurangan antara lain polimerisasi PMMA menghasilkan porositas yang tinggi, absorbsi air yang tinggi, perubahan volume dan sisa monomer. ${ }^{1}$

Perkembangan gigitiruan sebagian lepasan dengan bahan nilon termoplastik yang dikenal dengan gigitiruan fleksibel atau Flexi Denture merupakan alternatif untuk mengatasi keluhan pada gigitiruan kerangka logam dan akrilik. Menurut Anusavice (2004) bahan gigitiruan fleksibel bebas logam dan bebas dari sisa monomer yang umumnya menjadi penyebab reaksi alergi, bersifat translusen, cukup kuat, lebih ringan dan memiliki biokompatibilitas yang dapat diterima jaringan mulut. ${ }^{2}$ Warna dan bentuknya mampu menyerupai penampakan alami dari jaringan gingiva. Valplast ${ }^{\circledR}$ merupakan salah satu produk bahan gigitiruan fleksibel dengan fleksibilitas dan stabilitas yang sempurna apabila dibuat dengan ketebalan yang tepat. $^{2}$

Stabilitas warna adalah kemampuan lapisan permukaan atau zat warna untuk menolak degradasi karena kontak lingkungan. Perubahan warna pada basis gigitiruan fleksibel disebabkan oleh beberapa faktor seperti saliva, suhu pada rongga mulut, pola makan, air minuman yang berwarna, tekstur permukaan dan porositas dari material basis gigitiruan, lama penggunaan gigitiruan, dan kebersihan gigitiruan. Menurut Mc.Cabe dan Walls (2008), rata-rata suhu rongga mulut seseorang berkisar antara $32^{\circ} \mathrm{C}-37^{\circ} \mathrm{C}$ akan tetapi pada kenyataannya seseorang justru sering mengkonsumsi minuman panas dengan suhu lebih dari rata-rata suhu rongga mulut. Besarnya suhu dan frekuensi seseorang mengkonsumsi minuman panas pada kondisi tertentu kemungkinan akan berpengaruh pada perubahan warna basis gigitiruan fleksibel. ${ }^{3}$ 


\section{BAHAN DAN METODE}

Penelitian ini menggunakan 30 plat basis gigitiruan fleksibel berukuran $10 \mathrm{~mm} \times 10 \mathrm{~mm} \times 2 \mathrm{~mm}$, terdiri dari 10 kelompok dengan 3 buah plat per kelompok. Kelompok 1, 2, 3 direndam dalam suhu $40^{\circ} \mathrm{C}$, kelompok 4, 5, 6 direndam dalam suhu $50^{\circ} \mathrm{C}$ dan kelompok $7,8,9$ direndam dalam suhu $60^{\circ} \mathrm{C}$, dengan lama perendaman setiap kelompok 1,3 dan 5 menit diatur menggunakan stopwatch, kelompok kontrol direndam dalam suhu rongga mulut yaitu $37^{\circ} \mathrm{C}$. Perendaman plat untuk tiap kelompok dilakukan 2 kali sehari selama 14 hari berturut-turut, dilakukan dalam waterbath sebagai pengatur suhu. Plat basis gigitiruan fleksibel diamati perubahan warnanya setelah mencapai batas waktu perendaman yang telah ditentukan. Plat basis gigitiruan fleksibel dikeluarkan dari waterbath, selanjutnya ditempatkan pada alat pencahayaan objek untuk dilakukan pengambilan gambar dengan kamera digital. Data berupa gambar selanjutnya dimasukkan ke dalam Adobe Photoshop dengan metode CIELab. Sudut pencahayaan diatur sebesar $45^{\circ}$ agar pencahayaan yang dihasilkan lebih maksimal. Pengambilan gambar awal dilakukan sebelum plat direndam dalam waterbath akan membuat data lebih akurat dan gambar ini akan menjadi acuan bagi pengolahan data gambar-gambar selanjutnya.

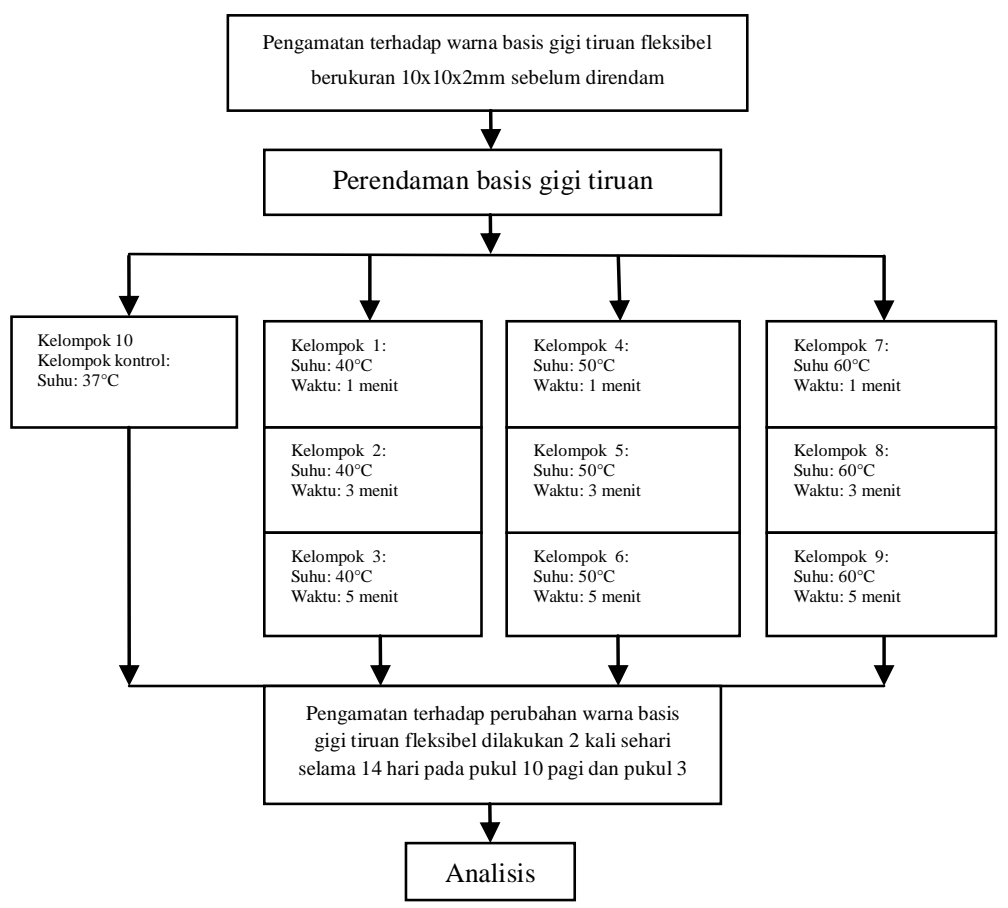

Gambar 1. Diagram alur penelitian

Pengukuran perubahan warna dilakukan dengan menggunakan kamera dan diukur menggunakan program Adobe Photoshop ${ }^{\circledR}$ untuk menentukan nilai $L^{*}, a^{*}$, dan $b^{*}$ menggunakan sistem CIELab. Nilai $L^{*}$ merupakan koordinat yang mempresentasikan cahaya suatu objek yang diukur dari skala 0-100, dimana 0 mempresentasikan warna hitam dan 100 mempresentasikan warna putih. Nilai $a^{*}$ merupakan koordinat yang mempresentasikan posisi warna objek pada skala hijau murni dan merah murni, dimana skala -120 mempresentasikan warna hijau murni dan skala +120 mempresentasikan warna merah murni. Nilai $b^{*}$ merupakan koordinat yang mempresentasikan posisi warna objek pada skala biru murni dan kuning murni, dimana -120 mempresentasikan warna biru murni dan +120 mempresentasikan warna kuning murni.

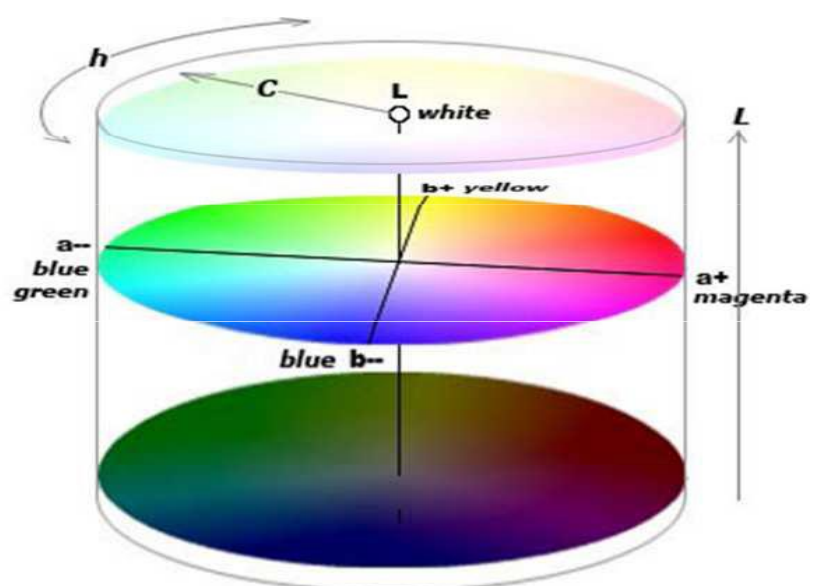

Gambar 2. CIELAB Color Model. ${ }^{4}$

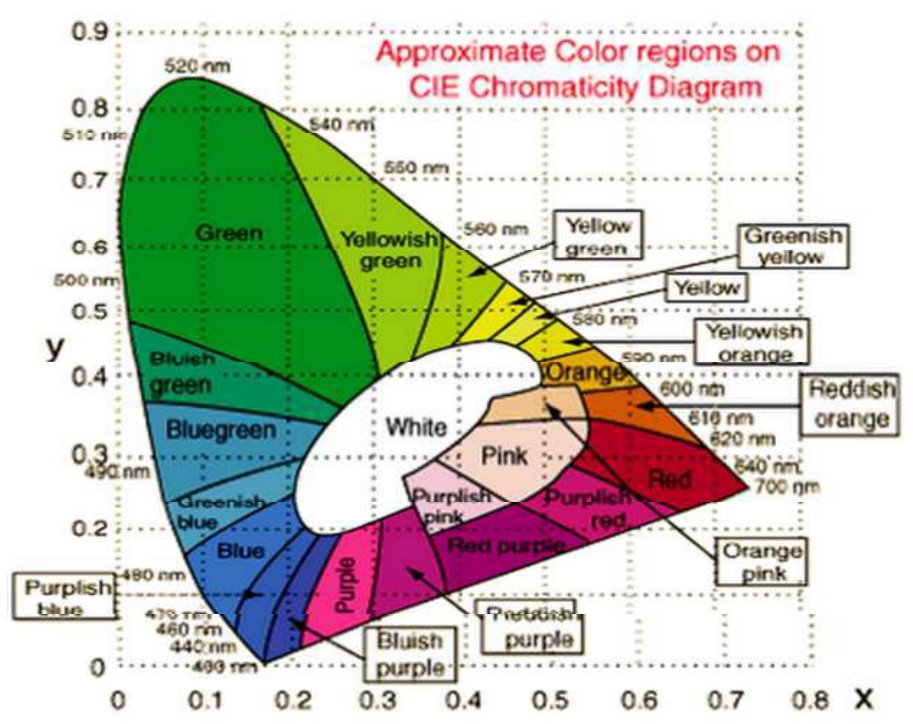

Gambar 3. Diagram Kromatisasi CIE. ${ }^{4}$

\section{HASIL DAN DISKUSI}

Hasil uji statistik menggunakan One Way Anova diperoleh nilai sig $0.000(\mathrm{p}<0.05)$, menunjukkan bahwa suhu $40^{\circ} \mathrm{C}, 50^{\circ} \mathrm{C}$ dan $60^{\circ} \mathrm{C}$ memiliki pengaruh yang signifikan terhadap perubahan stabilitas warna basis gigi 
tiruan fleksibel. Selanjutnya dilakukan uji LSD (Least Significant Deference) untuk mengetahui signifikansi perbedaan antara tiap kelompok perlakuan. Hasil uji LSD menunjukkan adanya perbedaan perubahan nilai warna yang signifikan antara kelompok suhu kontrol $37^{\circ} \mathrm{C}$ dengan suhu $40^{\circ} \mathrm{C}$, suhu $50^{\circ} \mathrm{C}$ dan suhu $60^{\circ} \mathrm{C}(\mathrm{p}<0.05)$. Sedangkan antara suhu $40^{\circ} \mathrm{C}$, suhu $50^{\circ} \mathrm{C}$ dan suhu $60^{\circ} \mathrm{C}$ tidak mempunyai perbedaan yang signifikan ( $p>0.05)$.

Hasil uji LSD menunjukkan adanya perbedaan yang signifikan terhadap perubahan nilai warna pada kelompok suhu $40^{\circ} \mathrm{C}$ antara kelompok lama perendaman 1 menit dan 3 menit dengan nilai sig $0.000 \mathrm{p}<0.05$, kelompok 1 menit dan 5 menit dengan nilai sig $0.000 \mathrm{p}<$ 0.05, serta kelompok 3 menit dan 5 menit dengan nilai sig $0.000<0.05$. Perbedaan yang signifikan terhadap perubahan nilai warna juga terdapat pada kelompok suhu $50^{\circ} \mathrm{C}$ antara kelompok lama perendaman 1 menit dan 3 menit dengan nilai sig $0.000 \mathrm{p}<0.05$, kelompok 1 menit dan 5 menit dengan nilai sig $0.000 \mathrm{p}<0.05$, serta kelompok 3 menit dan 5 menit dengan nilai sig $0.000<$ 0.05 . Demikian pula terdapat perbedaan yang signifikan terhadap perubahan nilai warna pada kelompok suhu $60^{\circ} \mathrm{C}$ antara kelompok lama perendaman 1 menit dan 3 menit dengan nilai sig $0.000 \mathrm{p}<0.05$, kelompok 1 menit dan 5 menit dengan nilai sig $0.000 \mathrm{p}<0.05$, serta kelompok 3 menit dan 5 menit dengan nilai sig $0.000<0.05$.

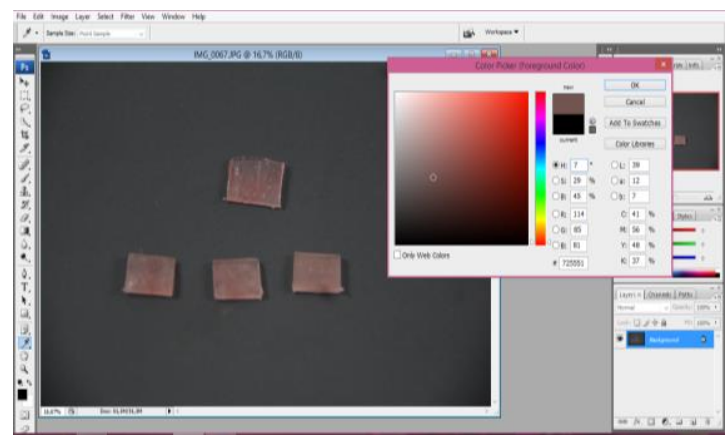

Gambar 5. Hasil CIELab

\begin{tabular}{|c|c|c|c|c|c|c|}
\hline \multirow[b]{2}{*}{$\begin{array}{l}\text { (I) } \\
\text { Waktu }\end{array}$} & \multirow[b]{2}{*}{$\begin{array}{l}(\mathrm{J}) \\
\text { Waktu }\end{array}$} & \multirow{2}{*}{$\begin{array}{c}\text { Mean } \\
\text { Difference } \\
\text { (I-J) }\end{array}$} & \multirow[b]{2}{*}{$\begin{array}{l}\text { Std. } \\
\text { Error }\end{array}$} & \multirow[b]{2}{*}{ Sig. } & \multicolumn{2}{|c|}{$95 \%$ Confidence Interval } \\
\hline & & & & & $\begin{array}{l}\text { Lower } \\
\text { Bound }\end{array}$ & Upper Bound \\
\hline \multirow[t]{2}{*}{$\begin{array}{l}1 \\
\text { Menit }\end{array}$} & $\begin{array}{l}3 \\
\text { Menit }\end{array}$ & $-.20000^{*}$ & .00000 & .000 & -.2000 & -.2000 \\
\hline & $\begin{array}{l}5 \\
\text { Menit }\end{array}$ & $-4.30000^{*}$ & .00000 & .000 & -4.3000 & -4.3000 \\
\hline \multirow[t]{2}{*}{$\begin{array}{l}3 \\
\text { Menit }\end{array}$} & $\begin{array}{l}1 \\
\text { Menit }\end{array}$ & $.20000^{*}$ & .00000 & .000 & .2000 & .2000 \\
\hline & $\begin{array}{l}5 \\
\text { Menit }\end{array}$ & $-4.10000^{*}$ & .00000 & .000 & -4.1000 & -4.1000 \\
\hline \multirow[t]{2}{*}{$\begin{array}{l}5 \\
\text { Menit }\end{array}$} & $\begin{array}{l}1 \\
\text { Menit }\end{array}$ & $4.30000^{*}$ & .00000 & .000 & 4.3000 & 4.3000 \\
\hline & $\begin{array}{l}3 \\
\text { Menit }\end{array}$ & $4.10000^{*}$ & .00000 & .000 & 4.1000 & 4.1000 \\
\hline
\end{tabular}

*. The mean difference is significant at the 0.05 level.

\begin{tabular}{|c|c|c|c|c|c|c|}
\hline \multirow[b]{2}{*}{$\begin{array}{l}\text { (I) } \\
\text { Kelompok }\end{array}$} & \multirow[b]{2}{*}{$\begin{array}{l}\text { (J) } \\
\text { Kelompok }\end{array}$} & \multirow{2}{*}{$\begin{array}{c}\text { Mean } \\
\text { Difference } \\
(\mathrm{I}-\mathrm{J})\end{array}$} & \multirow[b]{2}{*}{$\begin{array}{l}\text { Std. } \\
\text { Error }\end{array}$} & \multirow[b]{2}{*}{ Sig. } & \multicolumn{2}{|c|}{$\begin{array}{l}\text { 95\% Confidence } \\
\text { Interval }\end{array}$} \\
\hline & & & & & $\begin{array}{l}\text { Lower } \\
\text { Bound }\end{array}$ & $\begin{array}{l}\text { Upper } \\
\text { Bound }\end{array}$ \\
\hline \multirow[t]{3}{*}{37.00} & 40.00 & $21.10000^{*}$ & 1.23227 & .000 & 18.5984 & 23.6016 \\
\hline & 50.00 & $21.06667^{*}$ & 1.23227 & .000 & 18.5650 & 23.5683 \\
\hline & 60.00 & $19.83333^{*}$ & 1.23227 & .000 & 17.3317 & 22.3350 \\
\hline \multirow[t]{3}{*}{40.00} & 37.00 & $-21.10000^{*}$ & 1.23227 & .000 & -23.6016 & -18.5984 \\
\hline & 50.00 & -.03333 & .77936 & .966 & -1.6155 & 1.5488 \\
\hline & 60.00 & -1.26667 & .77936 & .113 & -2.8488 & .3155 \\
\hline \multirow[t]{3}{*}{50.00} & 37.00 & $-21.06667^{*}$ & 1.23227 & .000 & -23.5683 & -18.5650 \\
\hline & 40.00 & .03333 & .77936 & .966 & -1.5488 & 1.6155 \\
\hline & 60.00 & -1.23333 & .77936 & .123 & -2.8155 & .3488 \\
\hline \multirow[t]{3}{*}{60.00} & 37.00 & $-19.83333^{*}$ & 1.23227 & .000 & -22.3350 & -17.3317 \\
\hline & 40.00 & 1.26667 & .77936 & .113 & -.3155 & 2.8488 \\
\hline & 50.00 & 1.23333 & .77936 & .123 & -.3488 & 2.8155 \\
\hline
\end{tabular}

*. The mean difference is significant at the 0.05 level.

Nilon termoplastik merupakan basis gigi tiruan yang memiliki derajat fleksibilitas dan stabilitas yang sangat baik, tidak mudah patah, sehingga dapat dibentuk setipis mungkin, sehingga dapat beradaptasi baik dengan daerah gerong, biokompatibel, miring, resisten terhadap panas, bebas monomer sisa, dan hipoalergenik. ${ }^{5}$ Kekurangan bahan ini antara lain tendensi nilon untuk berubah warna pada suhu yang tinggi di atas rata-rata suhu rongga mulut, penyerapan air yang besar dan kekasaran permukaan meningkat setelah digunakan beberapa minggu. Penelitian Goiato (2010) menunjukkan nilai perubahan warna yang tertinggi secara signifikan pada bahan nilon termoplastik (Valplast ${ }^{\circledR}$ ) dibandingkan resin akrilik heat-cured. ${ }^{6}$

Diskolorisasi basis gigitiruan fleksibel disebabkan oleh dua faktor yaitu intrinsik dan ekstrinsik. Faktor intrinsik adalah perubahan kimia pada bahan itu sendiri yaitu proses polimerisasi yang tidak sempurna, pencemaran bahan pada waktu proses pembuatan bahan atau pengolahannya, akibat reaksi kimia di dalam bahan itu sendiri dan berbagai teknik pengolahan yang mengakibatkan terjadinya porositas pada permukaannya sehingga memudahkan penumpukan kotoran. ${ }^{6}$

Faktor ekstrinsik yaitu stain akibat absorpsi pigmen zat-zat pewarna dari sumber eksogen seperti larutan pembersih gigitiruan, makanan dan minuman berwarna, usia pemakaian bahan material baik karena kondisi fisika maupun kimia, dan perubahan suhu. Penyerapan suhu pada suatu bahan sebaiknya dipertahankan serendah mungkin karena suhu yang tinggi akan mempengaruhi stabilitas warna bahan tersebut. ${ }^{6}$ Nilon relatif tidak dipengaruhi oleh waktu simpan yang lama pada suhu kamar. Tetapi pada suhu yang lebih tinggi akan teroksidasi menjadi berwarna kuning dan rapuh dan mudah dipatahkan. ${ }^{5}$ Faktor ekstrinsik juga disebabkan penyerapan air melalui proses absorpsi dan adsorpsi yang dapat menyebabkan terjadinya staining dari resin 
disebabkan pigmen yang terdapat di rongga mulut sehingga terjadi perubahan warna dari resin tersebut.Adsorpsi adalah besarnya air yang terserap pada permukaan basis gigitiruan sedangkan absorpsi adalah penyerapan air ke bagian dalam basis gigitiruan. ${ }^{4}$

Hasil penelitian ini menunjukkan terdapat pengaruh suhu dengan lama perendaham terhadap perubahan warna basis gigi tiruan fleksibel $(\mathrm{p}<0,05)$. Pengaruh tersebut berupa kenaikan nilai rata-rata perubahan warna yang berbeda pada tiap kelompok perendaman. Hal ini terjadi karena adanya ikatan $\mathrm{NH}$ pada gugus hidroksi pada $\mathrm{H}_{2} \mathrm{O}$ sehingga banyak molekul air yang mengandung zat warna akan terikat pada nilon. Perubahan warna yang terjadi pada penelitian ini menggambarkan terjadinya akumulasi penempelan zat warna pada permukaan suatu bahan dan perlekatan partikel yang masuk ke bagian nilon termoplastik sehingga warna menjadi gelap. Nilon termoplastik dalam proses pembuatannya sudah dikemas dengan penambahan reinforced untuk mengurangi penyerapan air, akan tetapi fiber atau serat yang ada dalam nilon itu sendiri masih mempunyai kemampuan menyerap air. Hal ini merupakan salah satu faktor yang dapat mengakibatkan perubahan warna pada nilon termoplastik. ${ }^{7}$ Hasil penelitian menunjukkan bahwa terdapat perbedaan yang signifikan perubahan warna gigi tiruan fleksibel pada suhu kelompok kontrol maupun suhu kelompok perlakuan. Perubahan warna dapat terjadi melalui proses difusi, koefisien difusi dipengaruhi oleh suhu, semakin tinggi suhu maka koefisien difusi juga semakin meningkat sehingga menyebabkan perubahan warna semakin besar. ${ }^{8}$

\section{SIMPULAN}

Berdasarkan hasil penelitian dapat disimpulkan bahwa semakin tinggi suhu dan lama perendaman memiliki pengaruh yang signifikan terhadap perubahan warna basis gigi tiruan fleksibel.

\section{DAFTAR PUSTAKA}

1. Wurangian I. 2010. Aplikasi dan desain valplast pada gigitiruan sebagian lepas. vol 8, no.63. JITEKGI, Jakarta.

2. Anusavice KJ. 2004. Phillip:Buku Ajar Ilmu Bahan Kedokteran Gigi (10 ${ }^{\text {th }}$ ed.). Jakarta: EGC hal:197249.

3. Mc.Cabe JF, Walls AWG. 2008. Applied dental materials, Ed ke-9, Blackwell Munsgaard. London Assuncao, Barao, Tabata, dkk. 2009. Comparison between complete denture and implant-retained overdenture: effect of different mucosa thickness and resiliency on stress distribution, Gerodontology, Vol.26, No.4.

4. Pratomo. 2011. Warna-Color: Colorimetry Part IPart II. Makassar. Available from: http:// pengantarwarna.blogspot.com/favicon.ico

5. Prashanti E, dkk. 2011.Flexible Dentures : a flexible option to treat edentulous patients. Journal of Nepal Dental Association. Available from www.scribd.com/Flexible dentures A fl-exible option to treat edentulous

6. Goiato. 2010. Department of Dental Materials and Prosthodontics, Araçatuba Dental, Volume 21(4), hal:1270-1273.

7. Ulynnuha M, Yunisa F. 2012. Pengaruh lama perendaman nilon termoplastik dalam minuman kopi.

8. Craig RG, Powers JM. 2002. Restorative dental materials. 651-9, St.Louis: Mosby. 